\title{
Euro-illusion: A Natural Experiment
}

\author{
Edmund Cannon and Giam Pietro Cipriani
}

December 2003

\section{Discussion Paper No 03/ 556}

\author{
Department of Economics \\ UNIVERSITY OF BRISTOL \\ 8 WoOdLand Road \\ BRISTOL BS8 1TN \\ $\mathrm{UK}$
}




\title{
Euro-illusion: A Natural Experiment
}

\author{
Edmund Cannon $^{\mathrm{a}}$, Giam Pietro Cipriani ${ }^{\mathrm{b}}$ \\ ${ }^{\mathrm{a}}$ Department of Economics, University of Bristol, England \\ edmund.cannon@bristol.ac.uk \\ ${ }^{b}$ Department of Economics, University of Verona, Italy \\ g.p.cipriani@univr.it
}

December 2003

\begin{abstract}
We collect and analyse data on church collections to assess whether the introduction of Euro notes and coins had real effects on giving. Data for Italy suggests that money is not completely neutral while Irish data suggests a lower degree of money illusion.
\end{abstract}

JEL: E4; M3; Z12.

Keywords: Euro; money illusion; church giving; natural experiment.

\footnotetext{
${ }^{1}$ We thank Rebecca Fell, Sally Lane and Stephanie Leach for their help helped collect the data. We also wish to thank the Bishop of Verona, the Bishops of the Church of Ireland and the Anglican Bishop of Gibraltar in Europe for giving permission to contact the churches and to diocesan officers for assistance in collecting addresses and providing useful information.
} 


\section{Introduction}

The Euro 2002 Information Campaign, conducted by the Eurosystem (the European Central Bank and the national central banks of the euro area) made the introduction of the Euro notes and coins on the first day of 2002 a largely expected event of which most people were fully aware. In other words, this was a typical exogenous and fully anticipated nominal monetary shock. Standard economic prescription would then suggest that given no change in real variables, the real decisions of an optimising agent should not change either. In fact, any real change in individual behaviour would suggest a certain degree of money illusion.

The academic debate and a number of articles in the popular press before the change tried to predict the sorts of problems the Euro would create for consumers. One concern was administrative: would it be physically possible to distribute the notes and coins sufficiently quickly and how would agents respond to this possibility? In fact administrative problems of this nature appear to have been minimal.

A more interesting question for economists is the effect of the new currency on economic behaviour and three main channels through which behaviour would be affected were much discussed.

The first is a numerosity effect. People are familiar with a given set of nominal values in their national currency and the currency change would result in different nominal values. Soman, Wertenbroch and Chattopadhyay (2002) usefully categorise three ways that consumers' behaviour may depend upon these nominal values. The first is that consumers might respond in the way described by conventional microeconomic theory, exemplified in texts such as Deaton and Muellbauer (1980), in which case there would clearly be no money illusion.

An alternative response to different nominal values is that found by Raghubir and Srivastava (2002), who suggest that consumers anchor their behaviour to a base set of nominal values. A simple example would be of an American consumer who goes to Canada where nominal prices are higher than in the USA (since a Canadian dollar is worth less than a US dollar). Because of anchoring decisions to the base currency of the US dollar, the consumer would confuse the higher nominal prices with higher real prices and underspend. This is a clear example of money illusion. At least in the immediate aftermath of the introduction of the Euro, we might expect European consumers to continue to value their income (hence their budget constraint) in terms of the former national currency. In every country except Eire the conversion to the Euro led to lower numbers, so the anchoring effect should result in greater spending, with lower spending only in Eire (see Burgoyne et al., 1999). Consistent with this, Jonas et al (2002) find evidence that German people found salaries less attractive when paid in Euros and higher prices for consumer goods were estimated if these estimations were made in Euros compared to DM. Of course, as consumers became more used to the new currency, we should expect that increasingly they would not be using the former national currency as an anchor, so this effect should be temporary, even if the speed of adjustment is slow.

However, Soman et al. argue that money illusion is not actually a result of anchoring but an alternative phenomenon, which they refer to as difference assessment. They propose that money illusion could be explained by the numerosity heuristic (Pelham et al. 1994) rather than an anchoring process. The argument is that consumers may evaluate transactions in line with the numerosity of the difference between budget and prices (an approximate measure of their purchasing power). This prediction does not contradict Raghubir and Srivastava's result when prices and 
budgets are quoted in different currencies. However, when they are both quoted in the same currency the numerosity effect is predicted to produce the opposite results of the anchoring effect. In fact, Soman et al. (2002) provide experimental evidence to show that if numerosity increases (ie, all nominal values increase proportionately, including both the price of goods and the available money to be spent), then both total spending and spending patterns change: as the nominal values get larger, spending actually increases. If this effect is important, since the introduction of the Euro resulted in smaller numbers (except in Eire), we should expect spending to fall. Another effect that depends on the magnitude of the numbers involved is discussed by Marques (1999) who argues that because in most countries the conversion will lead to lower numbers, the quantitative differences between prices will be perceived as lower.

The discussion so far has concentrated on the psychological response of consumers to the size of numbers found in nominal prices, i.e. the numerosity. However, this need not be the only route through which changes in nominal prices could influence behaviour. Certain prices are more "attractive" than other prices and there may be a "1 Euro" effect: the unit of the new currency might become a new psychological threshold or base price. For example, in Italy 1000 lira, the smallest note in circulation, was considered a psychological threshold, and this rôle might be taken by the 1 Euro coin, worth almost twice as much. Folkertsma (2002) considers the role of "attractive prices": psychological, fractional and round prices. Since 90\% of prices of consumer goods in The Netherlands are "attractive", this paper measures the effects of a conversion of these guilder prices into the nearest upward attractive euro price. It finds that this psychological pricing could cause an increase of the CPI by $0.7 \%$ at most.

Finally, one might expect effects concerning the difficulty of performing conversion in everyday life. For example Italian consumers will tend to perform the conversion as if 1 Euro was equal to 2000 lira instead of 1936.27 which is the correct exchange rate.

The problem with both Soman et al (2002) and Raghubir and Srivastava (2002) is that the evidence is based on questionnaires of completed by relatively small numbers of students (fequently fewer than 100) in exchange for either course credit or small amounts of money $\$ 2$. So there are two potential problems: first, the students had no incentives to behave rationally; and second, there was relatively little time for students to fully think through the issues. Clearly an ideal experiment would have larger sample sizes, real quantities of money and last sufficiently long for any short run learning to take place. Other experimental studies also rely on on laboratory experiments (Fehr and Tyran, 2001) or survey questions, like Shafir et al. (1997), and thus one cannot really tell whether the results obtained would be observed in the real economy. Although there have been many changes in nominal values in currency due to revaluations or change in the system of money (e.g. the introduction of the New Franc in France about 40 years ago and of the decimal system in the UK in the 1970s), none has been as dramatic and on such a large scale as the introduction of the Euro. Also, to the best of our knowledge, there are no papers which have tried to explicitly study and measure money illusion using those historical cases.

The main novelty of this paper then is the use of a natural experiment to begin to test these competing hypotheses. In this paper we investigate the existence of money illusion by looking at Sunday's collections in churches in Ireland, Italy and some other European churches. Our data relate to a fairly large sample (in Eire, 23 thousand church attendances) and where agents are dealing with real sums of money (in Eire, $€ 103,000$ per year). It is true that one might ask whether church giving is 
fully determined by rational choice and clearly there are issues of donating money to support the provision of a semi-public good. Although there is not an extensive literature on this topic, Dean Hoge (1994) summarises the empirical findings in an introduction to a special issue on this topic in the Review of Religious Research (1994), concluding that "Religious giving is a rational behaviour and can be modelled using existing sociological and economic methods". ${ }^{2}$ Since many church-goers value the church enough to devote considerable quantities of time to supporting church activities, this is hardly surprising: furthermore if church-giving is subject to money illusion, then this would presumably have some consequences for other economic decisions even if only through the budget constraint.

The financial risks for the church in Europe due to the Euro's arrival were the subject of a number of newspapers and magazines articles around the time of the changeover ${ }^{3}$. For example, the Catholic Church in France was worried that the typical contribution at a Sunday Mass would drop by as much as $35 \%$. In fact, the typical contribution was FFr 10 in the form of a single coin. If that contribution was to be replaced by the 1 Euro coin there would be a $35 \%$ drop; if instead the 2 Euro coin was the replacement the value of the collection plate would increase by a third. In Italy the typical offer was the 1000 lira note. The question was what would replace that? If the replacement was a 1 Euro coin, collections would almost double. It it was a 50-cent coin they would slightly decrease. In Ireland many expected that the standard donation of $£ 1$ would be replaced by 1 Euro with a $20 \%$ fall in takings.

In fact, it soon became clear that some of these gloomy predictions did not become true (and the Irish Independent for example entitled an article "God be with euro for the generosity"). ${ }^{4}$ However, at least in some cases, there has been a real substantial effect following a nominal currency changeover as shown in this paper.

Data from Italian churches are analysed in Section II. Section III presents and discusses Irish and other European data. Section IV concludes.

\section{The Italian data}

From Italy we have a sample of 113 Roman Catholic churches from the Diocese of Verona: for each of these we have the total collection for the first 25 weeks of both 2001 and 2002. It is not customary to count the congregation in Roman Catholic churches and so we do not have information on congregation size. For each week we also know if there was something special about the service (e.g. a Baptism), which might make that week unrepresentative. Whenever a week $i$ had a special occasion in either 2001 or 2002 we usually exclude the data of both 2001 and 2002 from our analysis. ${ }^{5}$

Total giving for all of the churches is shown in Table 1 and rose by about 11 per cent between 2001 and 2002. ${ }^{6}$ If we include observations where there was a special occasion, we get the same result.

\footnotetext{
${ }^{2}$ Dahl and Ransom (1999) provides an example of such an analysis studying tithing donations and self-serving beliefs in the Mormon Church.

${ }^{3}$ See for example The Economist, "Survey: European Business and the Euro", Nov. 29 2001.

${ }^{4}$ See The Irish Independent, Jan. $21^{\text {st }}, 2002$.

${ }^{5}$ Analysis including such weeks resulted in almost identical conclusions.

${ }^{6}$ In our analysis we usually use the logarithm of the ratio of giving between the two years, i.e., $\ln \left(C_{2002, i}^{j} / C_{2001, i}^{j}\right)$, where $C_{t, i}$ is the collection in year $t$ and week (or month) $i$. The
} 
We need to compare this increase in giving with the increase that would have occurred if there had been no change in the coinage. Since church membership and attendance in Italy is almost static, we should expect giving to rise roughly in line with nominal income. Several measures of nominal income growth for Italy are shown in Table 2: in all cases they are much less than 11 per cent. Interestingly, growth in spending was the same as growth in income, so there appears to have been little impact of the Euro on total spending decisions.

Having established that there was a significant increase in church giving at the time of the introduction of the Euro, we now refine this analysis to see how the yearon-year giving varied by week and by church.

Figure 1 shows a cross-plot of the ratio of giving and the average giving for the 113 churches. It can be seen that there is no relationship between the amount of giving and the increase in giving, especially if one excludes three churches which appear to be outliers. ${ }^{7}$ Since these three churches have relatively low amounts of giving per week, it is reasonable to assume that they are quite small. Excluding these churches and taking the average of the ratios of giving in the remaining 110 churches, we obtain 11.5 per cent.

Alternatively we can see how the increase in church giving changed for different weeks of the year. Figure 2 graphs the mean ratio by week $i$, namely

$$
N_{J}^{-1} \sum_{j \in J} \ln \left(C_{2002, i}^{j} / C_{2001, i}^{j}\right)
$$

where $J$ is the set of non-special observations for week $i$ and $N_{J}$ is the corresponding sample size: the average number of churches for which we have data per week is 109 and the lowest number is 101 . Also plotted are the $95 \%$ confidence intervals based on the appropriate t-distribution. ${ }^{8}$ We note that Palm Sunday and Easter fell in weeks 14 and 15 in 2001 and in weeks 12 and 13 in 2002: since attendance and giving would have been higher in these weeks, we should expect a relatively high ratio for weeks 12 and 13 and a relatively low ratio in weeks 14 and 15, which is what we observe and thus the ratios for weeks 12 to 15 are not particularly informative. In addition, 6 January is the feast of Epiphany - a holy day of obligation and public holiday, which fell on the Saturday in 2001 and on the Sunday in 2002. The 2001 figure may include the collections for services on both the Saturday and the Sunday.

The temporal pattern of the increase in giving is interesting. For the first few weeks, the increase is negligible: in the first week giving appears to have fallen, probably due to the effect of Epiphany as just noted. ${ }^{9}$ Thereafter for mid-February to mid-March and from mid-April onwards, giving was always significantly higher than in the corresponding week of the previous year. For mid-March to mid-April the

advantage to using the log ratio is that it reduces the weight given to outliers when taking averages. However, using a simple ratio would give very similar results.

${ }^{7}$ An OLS regression yields a coefficient of -0.00004 for all 113 churches and 0.000009 if the outliers are excluded.

${ }^{8}$ The confidence intervals are for the mean ratio of giving by church. Thus if church $j$ had a ratio $R_{j}$, then the graph plots the mean value $N^{1} \Sigma_{j} R_{j}$ and the confidence interval for the mean of those church-specific ratios. Although this tells us little about the variance in the ratio of giving by persons, it is reported as the only measure of variance available.

${ }^{9}$ The first Sunday of 2002 was 6 January, so the new coins had been in circulation for almost a week. 
picture is more confused because of the changing date of Easter, but overall giving for this four week period also increased.

However, the initial lack of change in giving might be because donations were still being made largely in Lire: although the new coinage was introduced on 1 January 2002, the Italian Lira continued to be legal tender until 28 February 2002 and it remained possible to exchange the old national currency after that date: certainly the church data we have show some Lire continuing to circulate after February. Twenty three of the returns from Italy carefully separated the amounts donated in Lire and the amounts donated in Euros and we can use this sub-sample to estimate the importance of giving using the old coinage. The data are illustrated in Figure 3. We can see that the majority of giving was in Euros only after week 3, so it is possible taht the first few weeks show little change in giving because there had been little change in the currency in use. However, even when the new currency was in widespread use, many Italians may have continued to use the old currency.

As late as 2003, most Italians claimed to think in Lire rather than Euros, with 39 per cent always thinking in Euros and 30 per cent often doing so (L'Osservatorio Findomestic, 10th Edition, 2003-2004, p.18). With such a large number thinking in Lire, it would not be surprising that anchoring effects had a considerable effect.

This initially seems to contradict the result of Soman et al that the more important numerosity effect is through difference assessment. But of all the countries who changed to the Euro, Italy was the one where the change in numerical values was largest and where it was correspondingly difficult to make any meaningful comparison between the two prices. So it is possible that the process described by Soman et al is not applicable in this case.

Finally we should consider the rôle of rounding and threshold effects. If Italians gave a donation of the closest Euro round-number to the original Lire amount, they would have decreased giving by 3.3 per cent (since they would have approximated the exchange rate of 1936.27 by 2000), whereas if they had moved from an "attractive" amount of 1000 Lire to a $€ 1$, then giving would have increased by 93.6 per cent.

\section{Irish and European Churches}

Our second set of data are from Anglican churches in Eire (the Republic of Ireland) and mainland Europe. ${ }^{10}$ An advantage of this data is that Anglican churches count and record the congregation in every service. Since some of the variation in giving between 2002 and 2001 is likely to be due to variations in church attendance, having congregation figures provides an important control.

From Eire we have a sample of 77 churches from the Church of Ireland ${ }^{11}$ and from the rest of Europe we have a sample of 29 chaplaincies from the Anglican Diocese in Europe. As a control sample we have also collected data from 23 churches from the Church of Ireland in Northern Ireland, where the currency is £ sterling and there was no change in coinage. For these churches we only asked for data for the

\footnotetext{
${ }^{10}$ Anglican chaplaincies in Europe exist mainly to serve expatriates and have services in English: formally they are part of the Church of England.

${ }^{11}$ The Church of Ireland is the Anglican church which spreads across both Eire and Northern Ireland. Obviously the majority church in Eire is the Roman Catholic church: at the 1991 census Church of Ireland members constituted 2.5 per cent of the population in Eire.
} 
first Sunday of each month from January to July. ${ }^{12}$ As with the Italian data, services with a special event such as a Baptism are excluded.

Total giving and attendance figures are reported in Table 3. There is considerable variation in both the amount of giving per capita and the year on year change between the five Irish dioceses. This is partly because income per head varies regionally: Dublin and parts of Meath are richer than the rest of Eire and giving per head is higher. But there is an additional problem in that in some churches a substantial amount of regular giving is through weekly giving schemes (possibly even via bank standing order). Thus for some churches the plate collection is a relatively unimportant feature of giving and this is, for our purposes, an additional source of variability.

To test this we also consider the analogous figures for churches where the average weekly giving is greater than $€ 4:{ }^{13}$ for these churches the data we have is likely to reflect a significant proportion of regular giving to the church. But the figure for this sub-set of churches is 12.7 per cent, in line with the complete set of churches for which the figure is 13.2 per cent. ${ }^{14}$

When we consider a monthly breakdown of the data the picture is slightly different. Figures 4 and 5 show two measures of the ratio of giving; the first shows the average of the ratios for all churches, while the second takes a weighted average of the ratios, where the weights used are the average attendance for a church in a particular month. Analogously defined standard errors are also included. ${ }^{15}$ It can be seen that the averages are almost identical, but this is unsurprising since we know that the ratios of giving in 2001 and 2002 are uncorrelated with church size. However the standard errors are much smaller when we weight by church, consistent with data from larger churches averaging across the decisions of a larger number of individuals.

The increase in giving in the first six months is quite variable, with a noticeably larger increase in July. Given growth in income of about ten per cent, the increase in giving for the first six months is not much higher than we might have expected anyway. There is some evidence that there is an overall increase in giving in July. The temporal pattern of giving for our control sample of Northern Ireland is much more confusing. As shown in Figure 6, there is an overall tendency for giving to fall slightly at the beginning of 2002, offset by large increases in giving in April and June.

\footnotetext{
${ }^{12}$ These are weeks $1,5,9,13,18,22$ and 26 in 2001 and weeks 1, 5, 9, 14, 18, 22 and 27 in 2002. Thus the April and July observations are not the same week of the year. But the churches we sample tend to have a variety of services on a monthly basis, so the type of service on the first Sunday of the month (Holy Communion, family service, etc) will always be the same and thus comparable year on year. The weeks chosen do not include Palm Sunday or Easter Day; Anglican churches attach little importance to Epiphany so there would be no effect on the first observation of the year.

${ }^{13}$ The frequency distribution for giving per capita for each service in Eire is highly skewed, with a mode of about $€ 2$ and an obvious right tail beginning at about $€ 4$ (the distribution of the between group averages for each church is almost identical).

${ }^{14}$ A regression of the ratio of giving on the average level of giving yields a coefficient of 0.00678 , with a HCSE of 0.00926 . There is also no relationship between the ratio of giving and total giving or church congregation.

${ }^{15}$ Supposing that every individual church member raised their giving by a ratio of $R_{i}$, the correct statistic to use would be $N^{-1} \sum_{i} R_{i}$ where $N$ is the sample size. Since we only observe average giving within each church, we cannot calculate this statistic, but taking a weighted average with weights proportional to church size will provide a reasonable approximation.
} 
Although the increases in giving are comparable to those in Italy, the Irish figures do not suggest such a strong effect of the change in currency on behaviour, because the economy was growing much faster in Ireland, as can be seen in Table 4 . Unfortunately, regional GDP data for Eire and GDP data for Northern Ireland distinct from the rest of the UK are currently unavailable, so the comparisons of church giving growth and income and spending growth must be imperfect. ${ }^{16}$ Interestingly there was a significant difference between growth in GDP and growth in consumption in Eire, with total consumption spending rising less fast than income: in itself this might be partly due to the effect of the Euro and would be prima facie evidence for anchoring. However, extracting that part of the change in the savings ratio due to money illusion compared with other causes is beyond the scope of the present paper. What is clear is that giving in Eire rose slightly more than income but grew much faster than consumers' overall spending. The problem with interpreting this result is the behaviour of giving in the control sample, since giving in Northern Ireland actually rose at a faster rate than income or expenditure, despite there being no change in currency. It may be the case that the response in giving was largely due to the efforts of the Church of Ireland (in both north and south) to get church members to think about their overall giving.

Relating our empirical results to the theoretical discussion, it is worth noting at the outset that we cannot so easily determine the effects of rounding or threshold effects numbers. If the exchange rate of IR£0.787 to the Euro were approximated by 0.8 , then giving would only increase by 1.6 per cent, which would clearly be difficult to identify. As for "attractive" prices, IR£1 could be replaced by either $€ 1$ or $€ 2$, resulting in changes of -21.3 per cent or +57.4 per cent or, if Irish church-goers adopted a variety of strategies, any number within this range.

However, unlike the Italian case, we do have evidence for Soman et al's difference assessment, since giving clearly rose. One of the reasons for this increase to be relatively small is that this effect may have been attenuated by the opposite effect of anchoring.

For completeness, Table 3 also reports data on European churches. Our tentative conclusion is that giving per capita fell in France, Germany, Belgium and possibly Spain, while it rose in The Netherlands. These data are less significant than our two main cases given the smaller number of observations. Also, in some cases like Spain, they may be unrepresentative since they may include some chaplaincies whose congregations are predominantly tourists. Again there is evidence against anchoring, since giving fell in all cases except the Netherlands.

It is interesting to note that Germany and The Netherlands, with similar exchange rates with the Euro have opposite behaviour. The relevant exhange rates are 1 German DM $=€ 1.95583$ and 1 Dutch Guilder $=€ 2.20371$. So some of the change in giving could be due simply to rounding error: if people approximated these numbers with 2 , then we should expect giving to have fallen by 2.3 per cent in Germany and risen by 9.2 per cent in the Netherlands.

Belgium and France had substantially different exchange rates to the other countries, the rates being respectively $40.3399 \mathrm{BFR}=€ 1$ and 6.55957 FFR $=€ 1$. So for these two countries the numerical difference between salaries and prices in the original currency is not only much larger than in the new currency, but also the magnitude of the change is much larger than for any of the other countries. According to Soman et al's theory of difference assessment, Belgium and France

\footnotetext{
${ }^{16}$ In both cases the latest available disaggregated data is for 1999.
} 
should thus have the largest fall in giving. There is certainly some weak evidence for this happening in France, where the fall is substantial and our estimates are based on large attendance figures, but much less so in Belgium.

\section{Conclusion}

Our analysis of church giving provides strong evidence for the non-neutrality of money in parts of Europe. However, the precise nature of the non-neutrality varies considerably. Nominal collections rose by 11 per cent in Italy and 13 per cent in Eire, but the latter figure may be due entirely to the high growth rate in Ireland. The reason for this clearly depends upon the nature of the departure from full rationality.

Soman et al. (2002) argue that changes in nominal values may affect behaviour through a process of "difference assessment", which would result in lower church giving in every country except Eire: this can be contrasted with the phenomenon of "anchoring" proposed by Raghubir and Srivastava (2002), which would result in higher church giving in every country except Eire. The problem with both of these lines of research is that the evidence is based on laboratory experiments where there was no significant cash reward and were the reward provided little incentive to reveal correctly one's preferred behaviour. Furthermore, since it is likely that agents need some time to think through the consequences of changed nominal values, the time available in a brief laboratory experiment will typically be too short for them to fully assimiate the information.

In fact we find higher church giving in both Italy and Eire. For Eire, this suggests that difference assessment does explain the response to the nominal shock. If an anchoring effect is also present in Irish church giving, it is clearly outweighed by the stronger effect of difference assessment.

In the case of Italy, difference assessment appears to have no rôle to play. But the actual change in the numerosity of the currency is so large that agents would have been unable to use difference assessment: Soman et al. (2002) only consider variations in currency of the order of magnitude of 10, whereas in the case of Italy the order of magnitude was 1000 .

Also interesting is the relatively large variation in responses of other European countries. To some extent this merely confirms our initial discussion of different possible effects (ie, anchoring, difference assessment, rounding and threshold effects), each of which may be more or less important given the nature of the nominal shock. All of the hypothesised effects are types of bounded rationality and there is no reason that boundedly rational behaviour will respond in an entirely consistent manner to shocks of different types and magnitudes.

We conclude that there is strong evidence that nominal shocks will be nonneutral and a particular form of non-rationality causing this may be "difference assessment". However, from our smaller sample of Anglican European chaplaincy giving data considerable variation remains in both the sign and magnitude of the effect. This is consistent with it being difficult in practice to find non-neutrality in long-run time-series data even if there appears to be non-neutrality in specific cases. 


\section{Appendix: questionnaires}

\section{Questionnaire for the Italian churches}

Parrocchia di

Cognome e Nome del Parroco:

Si prega di compilare la tabella indicando l'importo delle offerte raccolte durante le collette domenicali. Per l'anno in corso l'importo può essere indicato indifferentemente in lire o in euro scrivendolo nella colonna apposita. Se si hanno dati sulle offerte raccolte in lire e su quelle in euro si possono compilare entrambe le colonne.

\begin{tabular}{|l|l|}
\hline & Offerte in lire \\
\hline \hline & \\
\hline 7 gennaio & \\
\hline 14 gennaio & \\
\hline 21 gennaio & \\
\hline 28 gennaio & \\
\hline 4 febbraio & \\
\hline 11 febbraio & \\
\hline 18 febbraio & \\
\hline 25 febbraio & \\
\hline 4 marzo & \\
\hline 11 marzo & \\
\hline 18 marzo & \\
\hline 25 marzo & \\
\hline 1 aprile & \\
\hline 8 aprile & \\
\hline 15 aprile & \\
\hline 22 aprile & \\
\hline 29 aprile & \\
\hline 6 maggio & \\
\hline 13 maggio & \\
\hline 20 maggio & \\
\hline 27 maggio & \\
\hline 3 giugno & \\
\hline 10 giugno & \\
\hline 17 giugno & \\
\hline 24 giugno & \\
\hline & \\
\hline
\end{tabular}

\begin{tabular}{|l|l|l|}
\hline \hline & Offerte in euro & Offerte in lire \\
\hline \hline & & \\
\hline 6 gennaio & & \\
\hline 13 gennaio & & \\
\hline 27 gennaio & & \\
\hline 3 febbraio & & \\
\hline 10 febbraio & & \\
\hline 17 febbraio & & \\
\hline 24 febbraio & & \\
\hline 3 marzo & & \\
\hline 10 marzo & & \\
\hline 17 marzo & & \\
\hline 24 marzo & & \\
\hline 31 marzo & & \\
\hline 7 aprile & & \\
\hline 14 aprile & & \\
\hline 21 aprile & & \\
\hline 28 aprile & & \\
\hline 5 maggio & & \\
\hline 12 maggio & & \\
\hline 19 maggio & & \\
\hline 26 maggio & & \\
\hline 2 giugno & & \\
\hline 9 giugno & & \\
\hline 16 giugno & & \\
\hline 23 giugno & & \\
\hline & & \\
\hline
\end{tabular}




\section{Questionnaire for the other churches}

Church

Diocese

\begin{tabular}{|l|l|l|l|}
\hline 2001 & & & \\
\hline Date & Attendance & Collection & Special? \\
\hline $07-$ gen-01 & & & \\
\hline $04-$ feb-01 & & & \\
\hline $04-$ mar-01 & & & \\
\hline 01 -apr-01 & & & \\
\hline $06-$ mag-01 & & & \\
\hline $03-$ giu-01 & & & \\
\hline $01-$ lug-01 & & & \\
\hline
\end{tabular}

\begin{tabular}{|l|l|l|l|}
\hline $\mathbf{2 0 0 2}$ & & & \\
\hline Date & Attendance & Collection & Special? \\
\hline 06-gen-02 & & & \\
\hline $03-$-feb-02 & & & \\
\hline $03-$ mar-02 & & & \\
\hline 07-apr-02 & & & \\
\hline $05-$ mag-02 & & & \\
\hline $02-$ giu-02 & & & \\
\hline $07-$-lug-02 & & & \\
\hline
\end{tabular}

\section{Explanation of Questions}

Attendance Please insert Adult attendance at Main Sunday service If there was no service leave blank

If Adult attendance is not available then insert Total attendance and write "T" in the column "Special"

Please insert total collection: for 2001 in the original currency, for 2002 in Euros or

Collection original currency (but please say which!)

\section{Special giving.}

Please tick this box if there were any special occasion (eg a Baptism) which might affect

\section{Please also answer the following questions}

What was the electoral roll for 2001 ?

What was the electoral roll for $2002 ?$

What proportion (approximately) of giving is made through bank standing order?

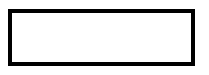

Do you raise significant amounts of money for the church through special collections (exclude collections for big projects such as repairing the roof)?

YES

NO

Would you like to receive a copy of the results of our research? 


\section{REFERENCES}

Burgoyne, Carole B.; Routh, David A. and Ellis Anne-Marie. "The Transition to the Euro: Some Perspectives from Economic Psychology." Journal of Consumer Policy, 1999, 22, pp. 91-116.

Dahl, Gordon B. and Ransom, Michael R., "Does Where You Stand Depend on Where You Sit? Tithing Donations and Self-Serving Beliefs." American Economic Review, September 1999, 89(4), pp.703-727.

Deaton, Angus and John Muellbauer. Economics and Consumer Behavior, New York, Cambridge University Press, 1980.

Fehr, Ernst and Tyran, Jean-Robert. "Does Money Illusion Matter?" American Economic Review, December 2001, 91(5), pp. 1239-1262.

Folkertsma, Carsten K. "The Euro and Psychological Prices: Simulations of the Worst-Case Scenario.” De Economist, March 2002, 150(1), pp. 19-40.

Hoge, Dean. "Introduction: The Problem of Understanding Church Giving." Review of Religious Research, December 1994, 36(2), pp. 101-110.

Iannaccone, Laurence R. "Skewness Explained: A Rational Choice Model of Religious Giving." Journal for the Scientific Study of Religion, 1997, 36(2), pp. 141157.

Jonas, Eva; Greitemeyer, Tobias; Frey, Dieter and Schulz-Hardt, Stefan. "Psychological Effects of the Euro - Experimental Research On the Perception of Salaries and Price Estimation." European Journal of Social Psychology, 2002, 32, pp. 147-169.

Marques, J.F. "Changing 'Europe'. The Euro as a New Subject for Psychological Research in Numerical Cognition” European Psychologist, 1999, 4, pp. 152-156.

Pelham, Brett W., Sumarta Tin Tin and Myaskovsky, Laura. "The Easy Path from Many to Much: The Numerosity Heuristic." Cognitive Psychology, 1994, 26, 103 133.

Raghubir, Priya and Srivastava, Joydeep, "Effect of Face Value on Product Valuation in Foreign Currencies" Journal of Consumer Research, 29, December 2002.

Shafir, Eldar; Diamond, Peter and Tversky, Amos. "Money Illusion.” Quarterly Journal of Economics, May 1997, 112(2), pp. 341-374.

Soman, Dilip; Wertenbroch, Klaus and Chattopadhyay, Amitava. "Currency Numerosity Effects on the Perceived Value of Transaction." INSEAD Working Paper Series, 2002, 124/MKT. 
Table 1: Italian church collections (sample of 113 churches)

\begin{tabular}{|l|l|l|l|}
\hline Italian Church Collections & 2001 & 2002 & $\ln \left(C_{2002, i} / C_{2001, i}\right)$ \\
\hline Excluding "special” weeks & $€ 1,227,413$ & $€ 1,370,457$ & 0.110 \\
\hline Total collections & $€ 1,291,269$ & $€ 1,438,195$ & 0.108 \\
\hline
\end{tabular}

Table 2: Growth in Italian nominal income from 2001 to $2002^{17}$

\begin{tabular}{|l|l|}
\hline GDP growth (market prices) & $3.13 \%$ \\
\hline Personal Disposable Income growth & $2.62 \%$ \\
\hline Consumers' Expenditure growth & $3.42 \%$ \\
\hline
\end{tabular}

Table 3: Church collection data for Anglican churches in Eire and Europe

\begin{tabular}{|c|c|c|c|c|c|c|c|c|c|}
\hline $\begin{array}{l}\text { Diocese/ } \\
\text { Country }\end{array}$ & $\begin{array}{l}\text { No. of } \\
\text { churches }\end{array}$ & $\begin{array}{l}\text { No. of } \\
\text { Obs. }\end{array}$ & $\begin{array}{l}\text { Attendance } \\
2001\end{array}$ & $\begin{array}{l}\text { Giving pc } \\
2001\end{array}$ & $\begin{array}{l}\text { Attendance } \\
2002\end{array}$ & $\begin{array}{l}\text { Giving pc } \\
2002\end{array}$ & $\begin{array}{l}\text { Total Giving } \\
\text { growth rate }\end{array}$ & $\begin{array}{l}\text { Attendance } \\
\text { growth rate }\end{array}$ & $\begin{array}{l}\text { Giving pc } \\
\text { growth rate }\end{array}$ \\
\hline Cork & 12 & 83 & 3868 & $€ 1.59$ & 3807 & $€ 2.01$ & $22 \%$ & $-2 \%$ & $23 \%$ \\
\hline Limerick & 7 & 42 & 1282 & $€ 4.26$ & 1398 & $€ 4.24$ & $8 \%$ & $9 \%$ & $0 \%$ \\
\hline Meath & 9 & 53 & 1976 & $€ 5.10$ & 1812 & $€ 6.14$ & $10 \%$ & $-9 \%$ & $19 \%$ \\
\hline Cashel & 23 & 120 & 4342 & $€ 2.57$ & 4128 & $€ 3.14$ & $15 \%$ & $-5 \%$ & $20 \%$ \\
\hline Dublin & 26 & 169 & 11740 & $€ 4.95$ & 10976 & $€ 5.58$ & $5 \%$ & $-7 \%$ & $12 \%$ \\
\hline All Eire & 77 & 467 & 23208 & $€ 3.92$ & 22121 & $€ 4.47$ & $8 \%$ & $-5 \%$ & $13 \%$ \\
\hline $\begin{array}{l}\text { Northern } \\
\text { Ireland }\end{array}$ & 23 & 134 & 14716 & $£ 3.40$ & 14268 & $£ 3.79$ & $8 \%$ & $-3 \%$ & $11 \%$ \\
\hline Belgium & 3 & 19 & 1228 & $€ 3.85$ & 1095 & $€ 3.59$ & $-18 \%$ & $-11 \%$ & $-7 \%$ \\
\hline France & 8 & 52 & 2411 & $€ 9.38$ & 2301 & $€ 7.86$ & $-22 \%$ & $-5 \%$ & $-18 \%$ \\
\hline Germany & 3 & 12 & 647 & $€ 4.87$ & 744 & $€ 3.85$ & $-9 \%$ & $14 \%$ & $-23 \%$ \\
\hline Spain & 5 & 33 & 3002 & $€ 3.06$ & 3107 & $€ 3.04$ & $3 \%$ & $3 \%$ & $-1 \%$ \\
\hline Netherlands & 5 & 21 & 2463 & $€ 3.45$ & 2198 & $€ 3.88$ & $0 \%$ & $-11 \%$ & $12 \%$ \\
\hline
\end{tabular}

Table 4: Growth rates of income in Ireland, 2001-2002 $2^{18}$

\begin{tabular}{|lll|}
\hline & $\begin{array}{l}\text { Consumers' } \\
\text { expenditure } \\
\text { growth rate }\end{array}$ & GDP \\
Eire & $8.3 \%$ & growth rate \\
UK & $7.8 \%$ & $12.1 \%$ \\
\hline
\end{tabular}

\footnotetext{
${ }^{17}$ The measure used for disposable income is "reddito nazionale disponibile netto", while that used for consumers" expenditure is "spesa delle famiglie". An alternative measure of consumers' expenditure would be "spesa per consumi finali nazionali", which grew at 3.26 per cent.

${ }^{18}$ Growth rates are comparing the first and second quarters of each year.
} 
Fig. 1

Ratio of Giving and Average Giving: Cross-section

Sample of 113 Italian churches

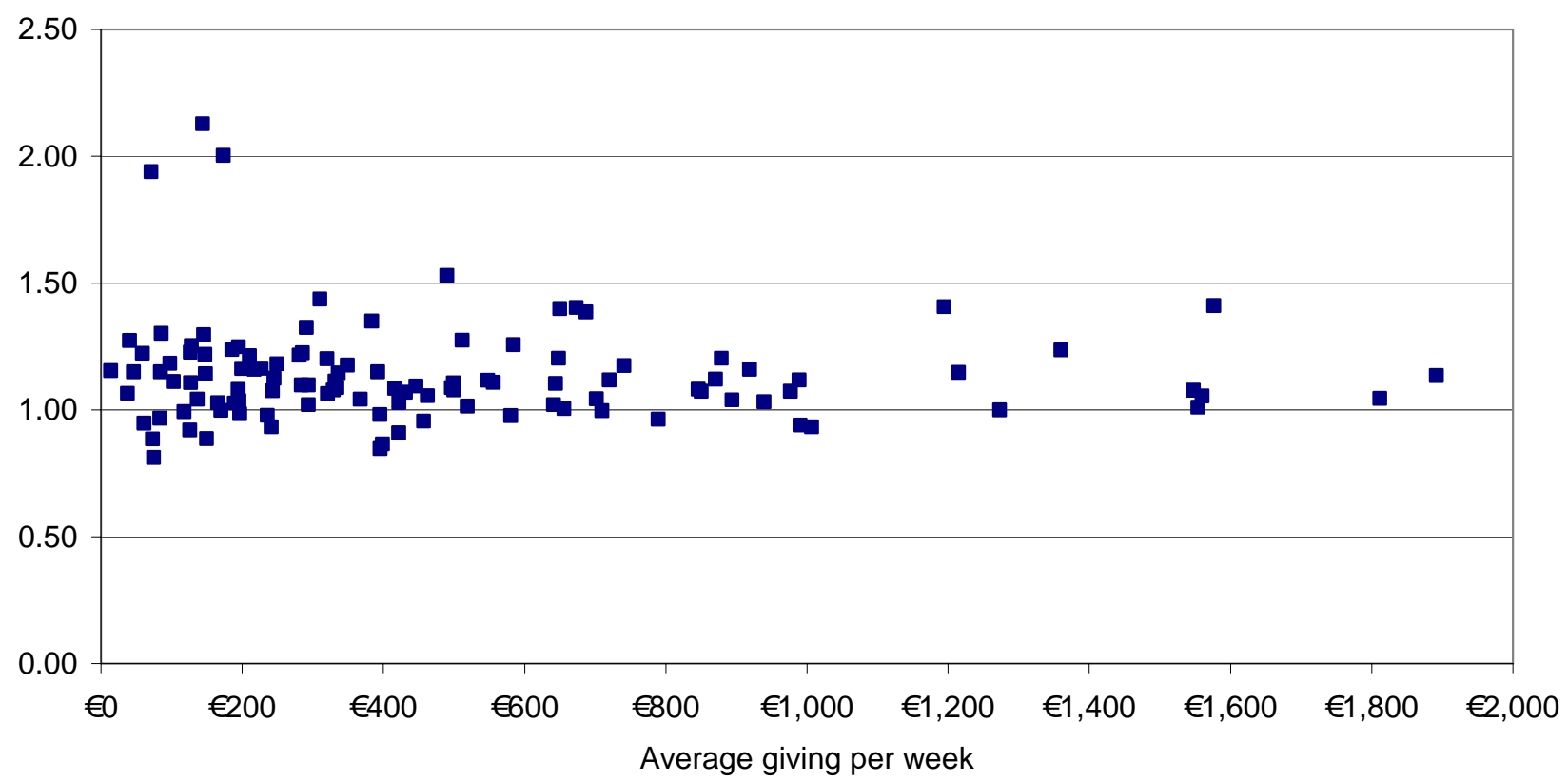

Fig. 2

Difference in Log Giving in Italian Churches Comparing giving in week $i$ of 2002 with giving in week $i$ of 2001 Mean difference and $95 \%$ confidence intervals

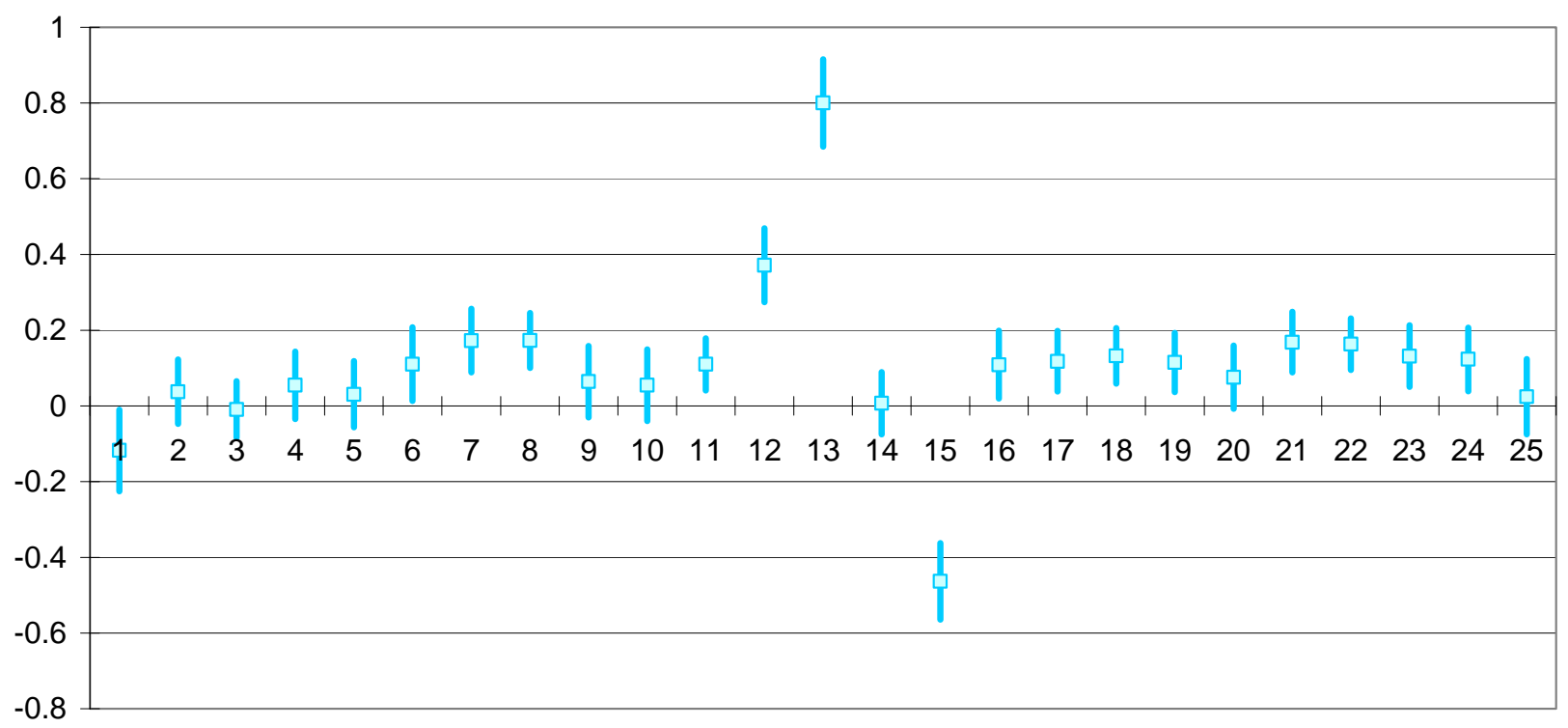


Fig. 3

\section{Composition of Giving in Lire and Euros}

Average giving from 23 churches by week of the year

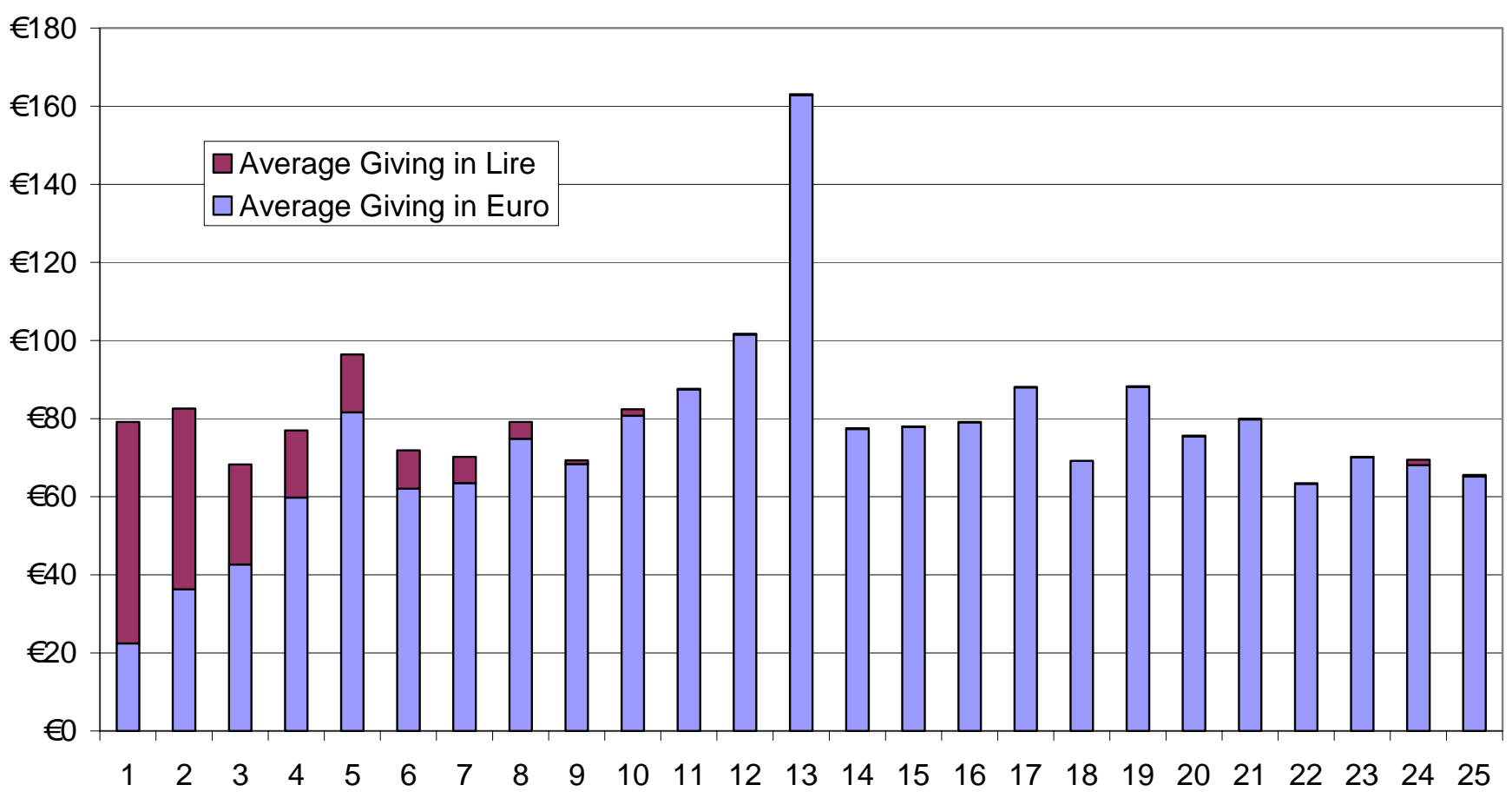

Fig. 4

Ratio of Giving: Eire (unweighted)

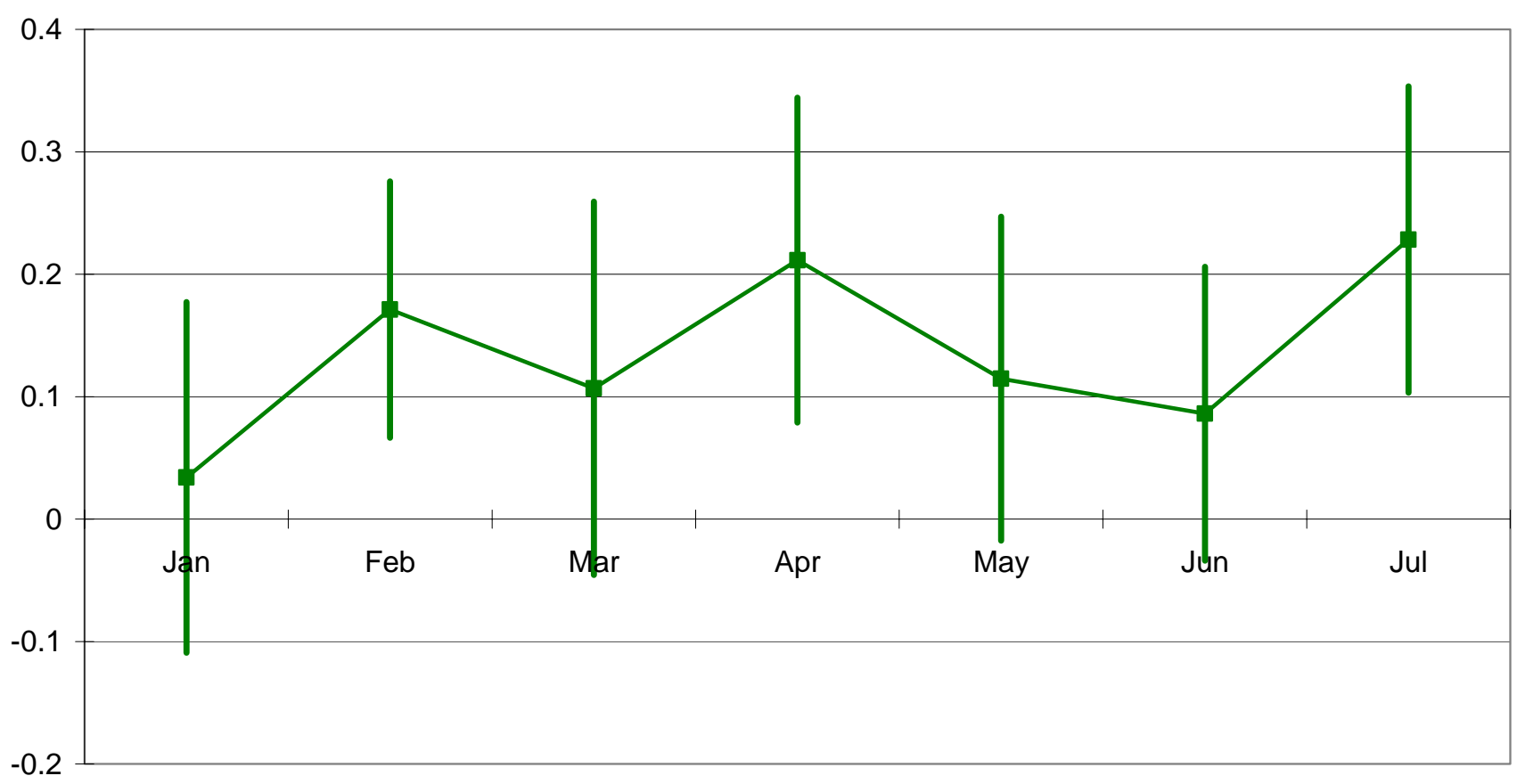


Fig. 5

Ratio of Giving: Eire (weighted)

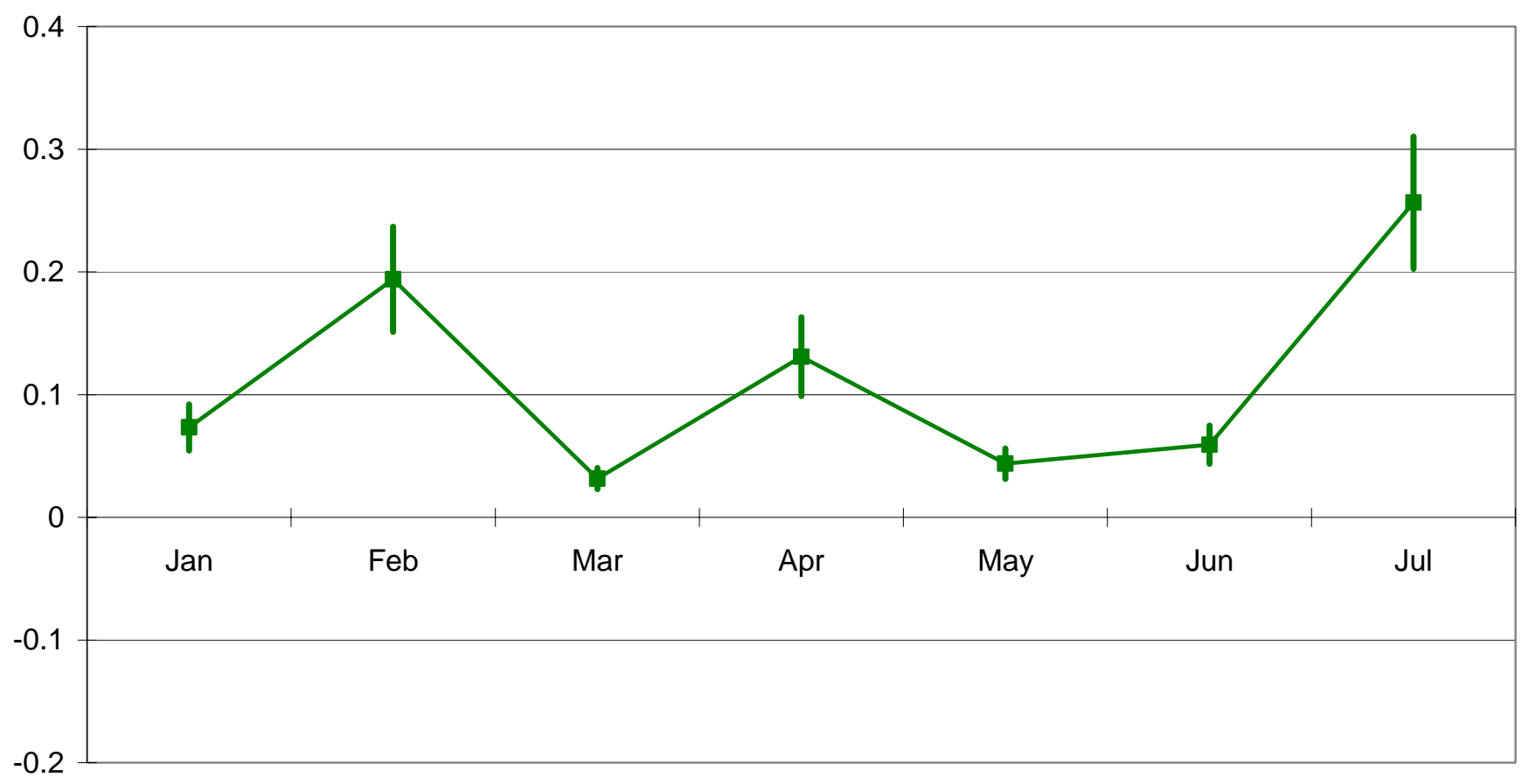

Fig. 6

Ratio of Giving: Northern Ireland (weighted)

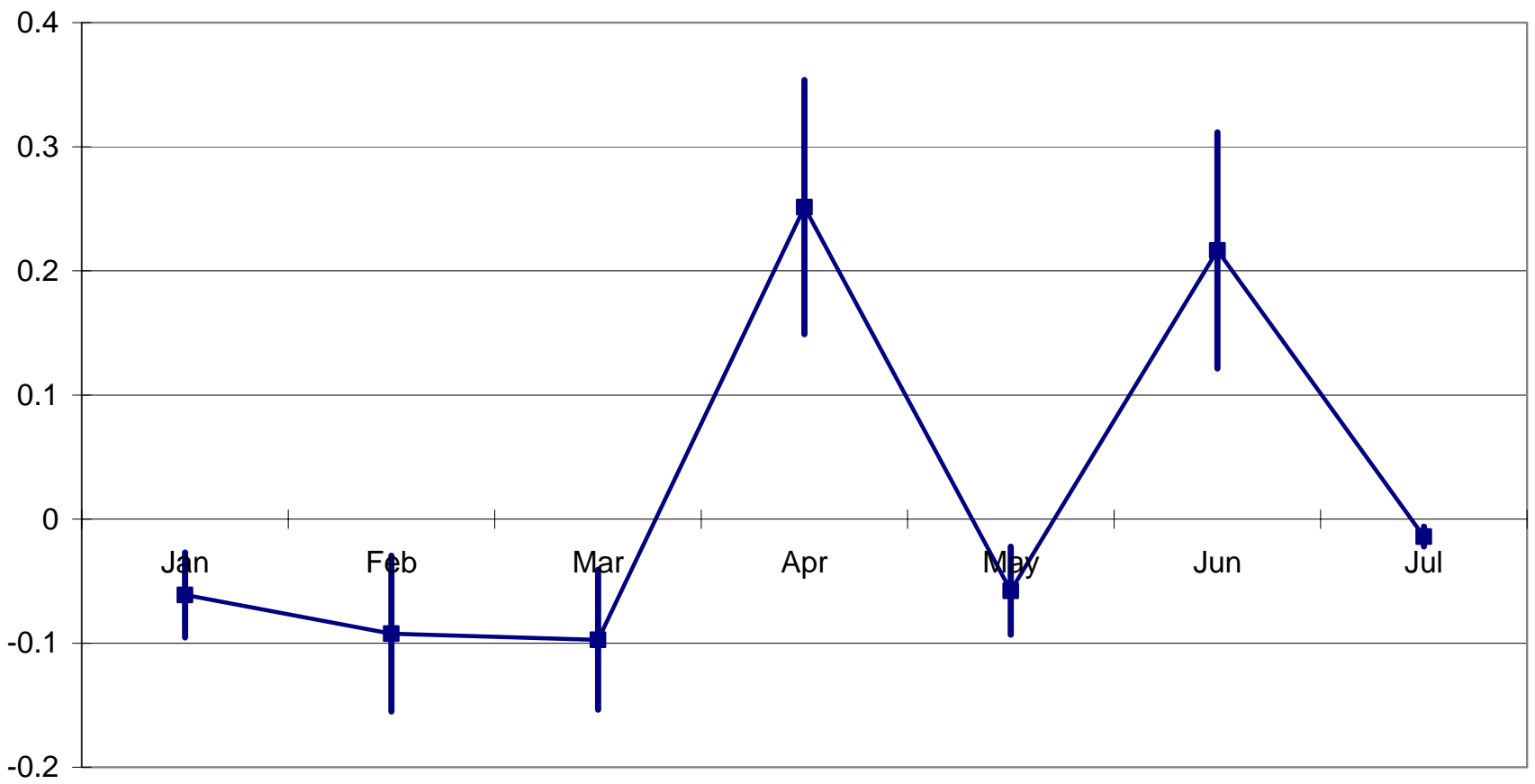

